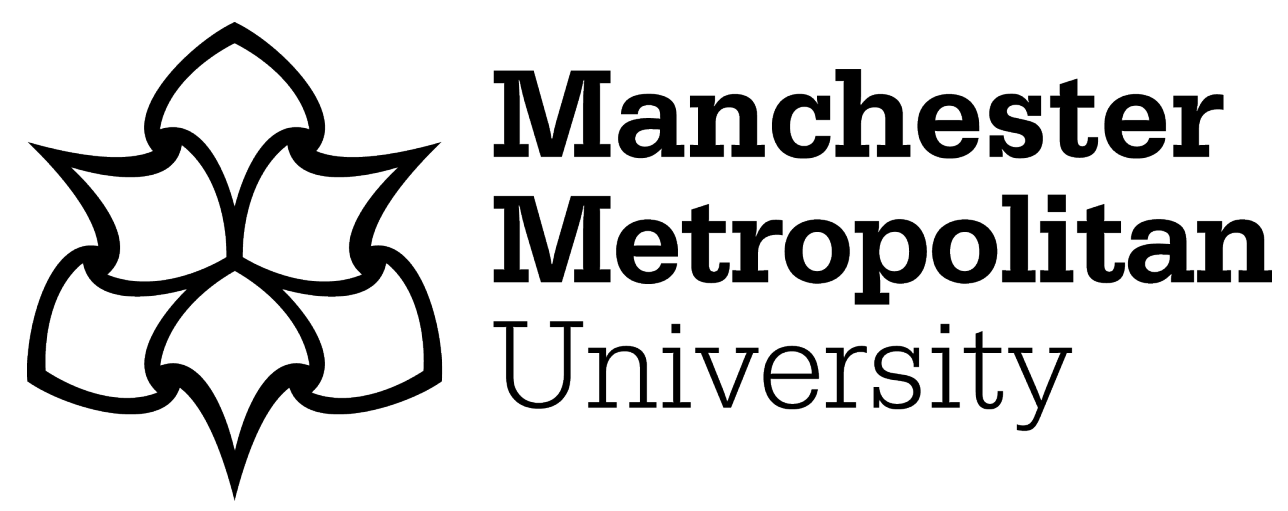

Carpenter, G (2015) Textual Fumbles: Reading and Seduction in Elizabeth Jane Howard's Falling. Contemporary Women's Writing, 9 (2). pp. 182-199. ISSN 1754-1484

Downloaded from: https://e-space.mmu.ac.uk/621061/

Version: Accepted Version

Publisher: Oxford University Press

DOI: https://doi.org/10.1093/cww/vpu015

Please cite the published version 


\section{Textual Fumbles: Reading and Seduction in Elizabeth Jane Howard's Falling}

The Spring 2012 edition of Novel: A Forum on Fiction opens with a collection of short essays that respond to the question 'What Can Reading Do?' The respondents are drawn from a wide range of academic disciplines and serve as testament to, as Ellen Rooney observes in her introduction, 'the burgeoning interest in recent years in the theory and practice of reading and the array of new critical approaches that have developed, both within novel studies and across the humanities'(1). ${ }^{1}$ This paper contends that debates about readers and reading are also being rehearsed and interrogated in the contemporary novel by women, in fictions that range across the full literary spectrum. That is, the reading subject and the subject of reading are deliberated in the writing that might be loosely labelled postmodern but also in more conventionally realist work which is more dependent upon processes of identification than playfulness and pastiche. The paper argues that careful attention to what I term the 'metareaderly' elements of realist fiction can reveal the ways in which this writing works to repeatedly question, challenge and resituate naturalised paradigms of reading. This claim will be illustrated via a close reading of Elizabeth Jane Howard's 1999 novel Falling which tells the story of a wounded woman's seduction by a duplicitous confidence trickster. The paper illustrates that analysis of the metareaderly features of Howard's novel can be used to reveal how she adeptly unpacks the discursive construction of (heterosexual) romance and reading in order to brutally expose some of their most powerful myths. This focus on the reading of romance as both text and discourse is a deliberate return to a series of debates that were prominent in the feminist literary academy in the 1980s and 1990s. Similar discussions are taking place in recent work on chick-lit ${ }^{2}$ and the phenomenon of the book group ${ }^{3}$ but this paper makes a specific link between the reading of romance and the romance of reading to argue that they are in continuing need of rigorous interrogation The 'textual fumbles' of the title of this work thus refers to both the utilisation of reading as foreplay and the slippage 
between the representation and realities of romance. The paper begins with a discussion of its theoretical frameworks before turning to an overview of Howard and the reception of her work as a precursor to the textual analysis.

\section{Critical Contexts}

Feminism and feminist literary theory has repeatedly engaged with the textual construction of romance from early second-wave condemnation of the genre as a pernicious tool of patriarchy; to work, encouraged by the academy's gradual acceptance of Cultural Studies, that sought to elucidate and theorise the pleasures that women readers take in popular romance; to more recent critiques and commentaries that seek to problematise and positively reposition romantic fictions. The romance reader ${ }^{4}$ has been relocated, shifting from a passive repository awaiting discursive interpellation to an active participant in the meaning-making process to a more complex, contradictory and nuanced subject who constitutes and is constituted by the text. This trajectory can be mapped through the dismissals of Greer, (214-5), Millett, (36-7), Friedan (61-70), to the detailed, recuperative analyses of Modleski and Radway, to the more interrogative work in Pearce and Stacey, Pearce and Wisker. Therefore, the textual romance highlights the repeated trivialisation of the woman reader / the woman writer / writing for women and the pleasures and/or disappointments that attend reading. Moreover, as Lynne Pearce has argued, the romance itself can itself be employed as a model for the relationship between reader and text. In Feminism and the Politics of Reading (1997) Pearce uses Roland Barthes' textual mapping of a love affair in A Lover's Discourse as an analogy for the reader/ text dynamic (81-186). Pearce claims that 'Barthes's typology of the romance trajectory as a journey from "ravissement" to "sequel" can be employed to describe the emotional components of reading, arguing that the gap that exists between the theory and practice of romance - the gap between the fantasy of the desire and its material enactment - is equally 
applicable to the analysis of reading (81). Pearce's specific project is to interrogate the disjunction that can occur for the feminist reader between a political and emotional response to a text. However, the romance paradigm can be more widely applied to fiction reading per se as it foregrounds the intoxication and hope for enlightenment that can often attend textual encounters whilst, conversely, allowing for reading to be as much about disappointment and disillusion as it might be about satisfaction and fulfilment. Congruent to both of these states is the idea that reading is a transformative practice: neither lover nor reader leaves their encounter unchanged. This correspondence between romantic desire and the love affair with the text is clearly magnified when the text in question is also a romance. Pearce is reflexively aware of the fact that this may be an easier paradigm to apply when the novels under discussion are themselves romances and/or the reader approaches the text with this model in mind (82) but, potential reductionisms aside, the analogy remains useful in its insistence upon reading as a process of shifting appetites and desires, that is, upon the importance of reading as a process of not only meaning-making but also of visceral and emotional affect.

If the reader's relationship with the text can be usefully characterised as a romance then how may this love affair be altered or skewed by the reading of a novel that specifically represents readers and reading? Here, the correspondence becomes a metatextual mirroring: reading the novel insists upon recognition by the material reader of the practice she is enacting whilst enacting it. This process of engagement might be labelled 'metareading' and the texts under analysis as 'metareaderly'. 5 In 'On Reading' (1986) Barthes uses 'meta-reading' to refer specifically to what he identifies as, 'the reading of reading' (33). This definition helps to articulate metareading as a practice which involves some form of reflection upon reading but which is also a practice of reading itself; it is a practice which works to highlight its own praxis. Like metafiction then, metareading is a production of the material reader's engagement 
with the text. Texts can only be labelled 'metareaderly' because of the doubling of the act of reading; the performance of reading by the reader is mirrored by its textual representation and vice-versa. In this duplication of the act of reading it seems that the metareaderly text induces a reflexive reading practice that is absent from metafiction. If metafiction works to position the reader in very particular and paradoxical ways with regard to the troubling of the boundary between fiction and reality - as critics from Lucien Dallenbach (1989), to Linda Hutcheon (1984) to Patricia Waugh (1984) have observed - then metareaderly texts further highlight the complexity of the relationships between reader, text and author; they interrupt the suspension of disbelief whilst concomitantly replicating the very process of textual consumption. The purpose of this insistent emphasis upon reading is to counteract the collocation of reading with passive consumption as compared to writing as an active, meaning-making practice. In 'Reading as Poaching' (1984) Michel de Certeau argues that writing and reading are hierarchised by 'the social and technical functioning of contemporary culture' whereby writing is valued more highly than reading: 'to write is to produce the text; to read is to receive it from someone else without putting one's own mark on it, without remaking it' (169). In de Certeau's opinion, writing and reading have been positioned as the constituents of a binary opposition whereby writing is the privileged term and reading the stigmatised other, necessary but unacknowledged. Of course, the process is actually one of mutual dependency, of symbiosis, yet, thirty years later, de Certeau's point remains valid: analyses of reading as a practice remain secondary to a continuing focus upon what Karen Littau (2006) labels 'reading for sense rather than sensation'(98). Thus, although metareaderly texts might also be classed as metafictional, the former term's focus upon reading and away from, often very arch, representations of storytelling, opens-up a wider range of fiction to critical analysis, for aligned to this privileging of writing and textual hermeneutics is the figure of the active male author in contrast to the woman reader as passive 
consumer of particular types of fiction. ${ }^{6}$ When these metareaderly fictions are also romances written by non-canonical women, and primarily directed at and consumed by the woman reader, then the process of de-stigmatisation, of recuperation and reclaiming, becomes threefold.

There is no shortage, in fact there is a panoply, of contemporary metareaderly romances by women writers in work ranging along a continuum from the highbrow to the popular. To give some examples: at one end are texts such as A.S Byatt's Possession (1990) and Jeanette Winterson's The PowerBook (2001), at the other are so-called 'chick-lit' novels such as Marian Keyes' The Other Side of the Story (2005) and Elizabeth Noble's The Reading Group (2004). In the more murky waters of the middlebrow lie works such as Diane Setterfield's The Thirteenth Tale (2006), Justine Picardie's Daphne (2008) and, indeed, Howard's Falling. Not only are debates about reading and readers being rehearsed in fiction by women but they repeatedly recur in the romance. However, authors like Byatt and Winterson are thought to deliver a very different type of reading sustenance than Setterfield and Picardie, let alone Keyes or Noble, and far more attention has been paid within the academy and without to this type of heavily intertextual, parodic and self-conscious writing. Romance is seemingly a genre of women's writing that often garners approval when delivered with a hefty dose of irony or postmodern playfulness but is largely denigrated or at best ignored when served-up straight (no pun intended). Things have perhaps progressed a little since Emma Parker claimed in 2004 that 'British women's writing has come to be represented, if represented at all, almost exclusively by Angela Carter and Jeanette Winterson' (7) but there is still as Nick Turner notes in 2010 'an explosion of interest in studying women writers who either can be fitted to a political position, or are in line with current theoretical trends: obvious examples are Angela Carter, Jeanette Winterson and Sarah Waters' (31). Both Byatt and Winterson are fully 
established as women authors worthy of academic scrutiny and debate, particularly in regard to their use of a postmodern aesthetic and the politics of reading, writing and identity. ${ }^{7}$ However, the messages about reading that inhere in much-debated work like Byatt's and Winterson's can be more conservative than those found in lesser-regarded fictions. Before unpacking this claim with direct reference to Howard's Falling it is worth spending a little time illustrating the ways in which highly sophisticated, reflexive fictions can concurrently reproduce reactionary models of reading.

The Booker prize-winning Possession is a novel that demands that literature and the literary be valued in their own right; it makes a clear case for the importance of reading but, ultimately, it is a very particular type of reading that is being promoted. Byatt's playfulness, intertextuality and parody locate her writing firmly within a postmodernist literary tradition but all these devices are annulled by the image, towards the close of the novel, of the young, late-twentieth century scholar Roland Michell re-reading a familiar poem: : 'He heard Ash's voice, certainly his voice, his own unmistakable voice, and he heard the language moving around, weaving its own patterns beyond the reach of any single, human, writer or reader' (472). This evocation of the transhistorical voice of the (male) poet reaching along the vast, intervening corridors of history to 'speak' to the contemporary reader relies upon a version of 'great' literature that ignores, in the name of art, the effects of history and also the material inequities of artistic production and consumption. Ultimately, Possession operates as affirmation of an Arnoldian/Leavisite literary sensibility whereby reading the right literature in the right way can civilise and elevate the individual. If, as Monica Flegel argues, Possession asks the reader to 'embrace a 'fairy-tale world' (427) then this fantasy extends to the fairy tale that too frequently attends the practices of reading and writing: that they are equally accessible to all. By contrast, in The PowerBook Winterson initially positions the 
relationship between reader and writer as one of economic exchange whereby the product and consumption of texts is bought, sold and haggled over in cyberspace as the reader/customer, Tulip, demands that the e-writer, Alix, change and craft the stories to suit her purchasing whims. However, when Alix and Tulip meet in the Matryoshka meatspace of the novel, these rather mechanistic, exchange-based models are counteracted as the pleasures and practices of reading become collocated with the enactment of desire. This is familiar Wintersonian territory as the novel maps the discourse of Christian sacrifice onto the discourse of romantic love ${ }^{8}$ : 'Love wounds. There is no love that does not pierce the hands and feet' (188). Winterson is also by no means averse to applying the language of Christianity to her worship of books: 'My books are a private altar. [...] I see no reason to refuse to bend the knee.' (1996 131). , As a paradigm for reading this is problematic for it implies that determination and suffering characterise the most fruitful textual encounters and that there are some types of readings and readers that are more desirable than others. Similarly, the open-endedness of The PowerBook's multiple and intersecting narratives is contradicted by the inference that the impossible may be achievable, that there is perhaps a way to access a superior level of understanding and textual pleasure. The preferred pleasure of the text - the 'found object[s]' (63), the 'buried treasure'(139) - derives from the consummation of the desires of authorAlix and reader-Tulip; a coming-together of ideal reader and ideal text which can, at best, achieve transcendence. ${ }^{9}$ This brief discussion of Possession and The PowerBook is deployed here to illustrate how texts that are often seen as ambitious and boundary-troubling can actually maintain or even promote conservatisms of reading. This paper now turns to Elizabeth Jane Howard as an example of a novelist who quietly interrogates the conventions of both reading and the romance.

\section{Elizabeth Jane Howard and Falling}


In Post-War British Women Novelists and the Canon, Turner claims that 'Howard lies somewhat forgotten and unread' (11). This is certainly an accurate assessment of her standing in the academy. Despite her longevity of career - her debut novel was published in 1950 and her last in 2013 - there is very little secondary critical work available on Elizabeth Jane Howard's writing, most comment is in newspaper reviews of her work or else in compendiums of contemporary and/ or British writers such as Heike Jüngst's (2002) and James Gindin’s (1996) accounts. Notwithstanding some ‘critical acclaim’ (Jüngst 155) being awarded to some of her earlier novels Howard is more renowned for her relationship with Kingsley Amis than her own writing. Jüngst observes that '[i]t is far easier to find comments on Elizabeth Jane Howard's marriages and childhood than serious analyses of her work. The majority of interviews center (sic) on her marriage to the writer Kingsley Amis, their lifestyle, and their subsequent breakup.'(157) An article by Christopher Fowler in The Independent in 2010 reveals the continuing fascination with Howard's love-life and society connections. Although Fowler praises her 'elegant prose 'and claims that she has recently 'stepped out from behind the lights of male authors', he simultaneously recommends 'her racy and rather moving memoir Slipstream, a volume that proves that the life of a writer especially a beautiful one - can be far from dull and sexless'. It was Howard's family saga quartet of Cazalet chronicles, published between 1990 and $1995,{ }^{10}$ that finally brought her some recognition as a novelist rather than as Amis's second wife and this was augmented by the dramatisation of the quartet by the $\mathrm{BBC}$ in 2001 . However, nothing else she has written, with the possible exception of Slipstream, has achieved the popularity of this historical chronicle of family life. In her review of the last book of the Cazalet quartet Claire Harman argues that 'Howard is not interested in writing about society or history, but about relationships, and specifically sex'(23). This statement, alongside Jüngst's remarks upon Howard's 'refusal to use experimental techniques' (154), devalues and undermines the 
subtleties of Howard's writing. The comments imply that a thematic focus upon human interaction and feeling/s identifies the writing, and by association the writer, as of little literary worth. This is, of course, a belief that has been repeatedly used to trivialise writing by women, most controversially perhaps in recent years by Ali Smith and Toby Litt's claim that women's writing is often 'disappointingly domestic, the opposite of risk-taking [...] dulled, good, saying the right thing, aping the right shape'. (x) It seems that Virginia Woolf's argument that '[t]his is an important book [...] because it deals with war. This is an insignificant book because it deals with the feelings of women in a drawing room' still holds powerful cultural resonance (70). '.11

Hence, Howard remains pigeon-holed as a rather lightweight novelist whose concerns remain those of what Nicola Humble, writing about earlier examples of this form, labels 'the feminine middlebrow'; a writer whose work 'straddles the divide between the trashy romance or thriller on the one hand, and the philosophically or formally challenging novel on the other: offering narrative excitement without guilt, and intellectual stimulation without undue effort.' (11) It is not my aim here to rescue Howard from her 'lightweight' status but rather to observe that the limited criticism available on Howard, journalistic and academic, would seem to concur with this version of her fictions. I want to argue that Howard's work is far more complex, more politically and aesthetically astute, than either Harman's or Jüngst's criticisms allow. Jüngst's comment follow her observation of some similarities between Howard and Austen with specific regard to 'comedies of manners' and 'country houses' (154). There are, indeed, correspondences between the two but they are more nuanced than Jüngst suggests. As Gindin has noted, Howard's writing exhibits 'a kind of moral control'(498) and she uses the tropes of social realism to expose and critique underlying normative structures, including a clear and consistent questioning of the construction of 
femininity/ies. Howard's novels have also been challenging in their own way, both thematically and stylistically, for example: Odd Girl Out (1972) details a three-way relationship between a married couple and a younger woman who comes to stay, including fairly explicit scenes of lesbian sex; an earlier novel, The Long View (1956), tells the story of a relationship in reverse, from end to beginning, an innovative structural device intended to differently dissect the anatomy of a marriage. It would be inaccurate to claim that Howard's work has been completely disregarded and the introductions to the re-issued editions of her earlier novels in the mid-1990s - as Pan-Macmillan capitalised upon the success of the Cazalet quartet - see other women writers paying testament to her particular strengths and insights as a novelist. In the 1995 edition of Odd Girl Out, Hilary Mantel comments upon how Howard 'approaches her characters with a blend of empathy and detachment which is unique to her' (vii) and concludes in asserting that she 'is one of those novelists who shows, through her work, what the novel is for' (xii). In the reissue of Howard's 1959 novel The Sea Change (1994) Sybille Bedford writes that 'Elizabeth Jane Howard's talent is as complex as it is original. I would call her a romantic realist of immense literary intelligence and range of insight' (ix-x). Howard's writing is undoubtedly ripe for re/reading and her recent death will hopefully refocus attention on her substantial and overlooked oeuvre. An analysis of Falling's metareaderly elements serves to foreground the complexity of all her work and this particular novel's subtly insistent interrogation of the very grand narratives upon which it is founded: the (heterosexual) romance and the romance of reading. ${ }^{12}$

Falling tells the story of a love affair between Henry Kent and Daisy Langrish and is delivered in two voices: the first-person narration of Henry and the third-person account of Daisy's experiences, although Daisy's chapters are increasingly supplemented by extracts from her journal. Henry is a confidence trickster of the highest calibre, calculatingly seeking 
out comparatively wealthy women to seduce in order that they might financially support him. Daisy is a successful playwright and television adapter who has had considerably less success in her personal life. When they meet, Henry is sixty-five and Daisy sixty-one; Henry is living alone on an ill-kept boat and Daisy has bought herself a country cottage to escape from London and the man that, ten years after their divorce, can still leave her 'gasping inwardly with pain' (34). Henry initially inveigles himself into Daisy's life by offering his services as a gardener yet gradually, and very deliberately, makes himself increasingly indispensable. Due to an injurious fall Daisy is hospitalised abroad and absent for a prolonged period, providing Henry with an opportunity to offer to finish her unpacking. By the time she returns he has begun a correspondence with her that has developed from prosaic questions about preferred garden flowers to detailed, entirely fabricated accounts of his upbringing and key love affairs which she consumes unquestioningly. Moreover, he has read, with her agreement, her play scripts and, with brazen audacity, her private letters, diaries and journals. Their early courtship is therefore massaged into being via conflicting models of reading - the uncritically passive and the unethically active- which are practices which will increasingly come to characterise the disastrous development of their relationship. Although Daisy is charmed by Henry's letters she takes care to keep him at a distance but when a subsequent further fall necessitates constant nursing Henry is conveniently on hand. He performs his self-scripted role with aplomb, gradually gaining Daisy's trust through his carefully executed thoughtfulness. The move from live-in nurse to lover is almost seamless as Henry shifts from tending her wounds to tending her wounded sense of self. The remainder of the novel details Daisy's increasing sexual and romantic infatuation with Henry until he exposes his violent side by hitting her when she refuses, for the second time, to marry him. Her daughter and friends have meanwhile been checking Henry's claims about his past and in the novel's dénouement call her back to London to reveal the truth about her mendacious lover. 
The novel is founded upon an experience of Howard's with a man who contacted her after hearing her interviewed on Radio Four's Desert Island Discs and the whole affair is detailed with a combination of candour and regret in Slipstream (460-6). She apparently fell for this man's charms in the same way that Daisy falls for Henry and, as in the novel, it was her family and close friends who uncover the fact that 'everything he'd told me, that they could verify, had been a pack of lies [...] There seemed to be nothing of the truth about him'(4656). Howard is very frank about what she clearly regards as her own foolishness in falling for the fiction that 'people didn't tell lies about love.' (466) The artistry of the novelisation of these events lies in its dual narration, as she imagines not only the character of Daisy but also that of Henry meaning that the reader too becomes caught in his web of knowing, unable to look away from this staged seduction. Fittingly, in view of Daisy's profession, the novel follows the structure of a play as her first fall in Mexico causes, literally and structurally, the disequilibrium, the unbalancing of the status quo. Her second fall, on her wet garden path following her homecoming, works to reinforce this state of upset so she is compelled to rely almost solely upon Henry. Henry may not engender the falls (although he has laid the path upon which she slips) but he scripts them fully to his advantage. Daisy's comment after her second fall - it's '[t]oo ridiculous [...] I seem to fall about like a drunkard' (250) - obviously prefigures the lack of control she will experience when in sexual thrall to Henry. Both falls make Daisy physically dependent and emotionally vulnerable and in this vertiginous state she becomes ripe for Henry's plucking. Falling thus operates as motif and metaphor throughout the novel as Daisy's literal falls are the catalyst for her falling for Henry, romantically and as victim. This collocation of romance with injury foreshadows the conclusion which inverts the closure of the typical romance. The imbalance caused by Daisy's 'falling' is rectified not by the traditional resolution of marriage but rather by the puncturing of the fantasy when she 
is wrenched from this state by the revelation of Henry's violence and cruelty. By virtue of the dual narration, Howard has the reader longing for relationship breakdown rather than consummation. Romance is therefore positioned as a site of duplicity; the fact that the seduction is scaffolded by and performed through various models of reading operates to locate reading as a similarly slippery and potentially deceptive practice.

In Howard's world reading is akin to romance: it can entice and entrance but can also be used to deceive and damage. As the novel progresses it gradually reveals the very personal and intimate costs of assuming reading to always be a civilising force for good. However, it is not just Daisy who is ensnared by this misjudgement; the reader too is often caught, and courted, by Henry's clever application of his literary knowledge. The novel begins with Henry stating that '[s]he has left me' and that '[t]his last, most terrible blow has knocked me out' (3). ${ }^{13} \mathrm{He}$ proceeds to narrate the story of his previous year but first outlines one of his many theories on women: that they are often 'mistreated' by men and that '[i]t has been [his] good fortune, and naturally [his] pleasure, to undo and heal some of this damage' (3). Thus Henry immediately locates himself as a sympathiser with abused women and in so doing forcefully interpellates the woman reader. His ideas are so pompously expressed and so reliant upon an unsophisticated homogenisation of gender that the reader is immediately wary of his claims. However, by the second page he is referencing George Eliot and, despite his rather condescending tone, this invocation of such a literary heavyweight lends him gravitas and draws the reader's attention. By the time he realises the cottage is occupied and has started contriving a meeting with the occupant he has mentioned his recent 'study of women novelists, both nineteenth- and twentieth-century authors' (5) and 'Iris Murdoch, Virginia Woolf, Ouida and Elinor Glyn' by name (11). This carefully selected list operates as a form of character reference and so persuasive is this recourse to a very particular type of literary 
knowledge that the moral discomfort engendered by his decision to invent an entire backstory in the personal columns is dismissed, and doubt counteracted by the flattery that attends his choice of character:

I decided that I should have been recently widowed [...] Suddenly the girl at Jane Eyre's terrible school came to mind - the clever, patient Helen Burns who died, you may remember, from tuberculosis after months of starvation, abuse and general neglect. Helen should be my dead wife whom I had nurtured until her end. (8) [my emphasis]

The effect of 'you may remember' coupled with the absence of Brontë's name is to stoke the reader's literary ego; it is assumed that Jane Eyre is a familiar text. His assessment of Daisy's Mercedes as 'a Gatsbyish car made for the privileged few' has a similar effect as the adjective is casually used and assumes certain knowledge (18). ${ }^{14}$

Thus the reader of the novel is being romanced alongside Daisy, charmed by Henry's deliberate dropping of intertextual references and the sense of a shared literary sensibility. It is exactly this sense of literary worldliness that works to captivate Daisy - when trying to persuade her daughter of Henry's pedigree she tells her that 'he's a tremendous reader' (331) - and she is also complimented by the fact that he looks to her for advice on reading plays, an area of literature of which he (cannily) claims ignorance. In his first letter of any length, Henry admits to Daisy that he has been unable to resist reading some of the many books that line her shelves - '[t]he sight of your shelves filled with volumes most of which were entirely new to me was too much' (151) - thus immediately establishing himself as a voracious reader. He tells her that he has realised that she is a well-known playwright and proceeds to meditate upon the difference between reading plays and novels: 'I see how much more poignantly plays can make a social point than novels seem to manage' and that ' $\mathrm{t}] \mathrm{his}$ is 
especially true in reference to women', noting how 'social values have changed since Ibsen's day' (151). This mention of the Norwegian playwright and the inevitable connotations of the doll's house sound a muffled warning to the reader but Daisy's response to Henry's queries is scripted by his adroit observations: she advises further reading and encourages him to read her own work. Henry discerns that:

[Plays] seemed as though they could be read much faster than a novel, but I quickly found that if they were any good this was not true. Plays had to be read more slowly, and with careful attention - preferably at least an act at a time.' (136)

There is a clear analogy here with his staged seduction of Daisy and, in presenting himself as a careful and attentive reader who is willing to learn more, Henry acquires status and some degree of reputability in Daisy's eyes.

Although Daisy's trust in Henry's romantic intentions is very painfully gained, her trust in the truth of his writing is almost immediate. As a potential lover she is stubbornly resistant, as a reader she resists nothing. ${ }^{15}$ In one of the letters that punctuate their early courtship Henry falsely tells Daisy that the reason he was forced to leave his first love, Daphne, was because she was revealed to be his half-sister. He actually highlights the unlikelihood of this scenario, commenting that it 'is more like a scene from a nineteenth century melodrama than anything else' (163), and Daisy responds in kind by exclaiming in her reply '[w] hat an extraordinary story [...] You describe the scene with Lady C so well that I almost felt that I was a witness, as though [...] I was at a play' (180) In many ways, unbeknownst to Daisy, this is exactly what she $i s$ witnessing; Henry is simultaneously performing for her and scripting her own performance. One of the tragedies of the novel is that the playwright fails to discern when she herself is being 'played'. What Henry is describing in the letter is actually much more an intertextual nod to D.H Lawrence's Lady Chatterley's Lover and here the material reader is once again flattered, this time at the fact that she recognises the allusion that eludes Daisy. 
This naïve acceptance of Henry's fiction-fuelled correspondence -Daisy's un-critical reading - simultaneously inverts and reinforces de Certeau's writer/reader binarism. The successful writer falls foul of the machinations of the careful reader as Henry utilises his literary capital to pen master(ing) works of deceit. while the duping of Daisy re-enacts a familiar model of the woman reader as passive receptacle for discursive inscription. This figure, of course, is recurrently represented in women's fiction itself: in many ways Howard's Daisy is a more contemporary version of Austen's Catherine Moreland, reading indiscriminately andwith wavering sense and sensibility, as both writers use this characterisation to critique ideologically sanctioned performances of romance.

Henry's ability to spin a convincing yarn is implied to be the result of the premature death of his beloved mother when he was only five. He paints a picture of being a lonely, misunderstood child who takes solace in reading and the alternative worlds offered by books. His mother told him that '[r] eading is the most important thing for you to learn in your life,' (78) so he retrieves the box of books from under her bed:

To begin with I read and reread the children's books that my mother had read me and some that she hadn't got to [...] but by the time I was eight I was reading Dickens, Somerset Maugham and Mrs Henry Wood (79-80).

When asked by his father's employer, Lady Carteret, what he wants to do with his life he proclaims: "I want to read books"”(84) and, amused by the unexpected ambitions of young Hal, she grants him access to the house's extensive library. He is so taken with the wealth and opportunity on display that he begins a 'game' whereby he imagines that he grows up to own and live on the estate. This game is fuelled 'from information gained from the books in my mother's box, and later, books lent to me from Lady Carteret's (or my) library' (88). Reading thus actively feeds his desire to escape the life mapped out for him and he uses the scenarios 
encountered in books to manipulate and deceive. Books enchant Henry but they also provide him with the devices with which to enchant others, in the repository of stories that they supply and the cultural capital with which they endow him. This Bourdeauian concept of cultural capital $^{16}$ is of particular relevance to this novel as concepts of class are such an intrinsic element of Henry's motivations and Daisy's misjudgements. Henry's working-class background is the overriding motor of his desire for money and status. He complains that 'there has always been something menial about being a gardener, which no quantity of upperclass, middle-aged ladies in green wellingtons can dispel' (13) and has a sophisticated awareness, via experience of its opposite, of the freedoms that money can bring: '[i]t was not so much that I wanted particularly to own a car like that Mercedes, but that I wanted to be in a position to choose whether I owned one.' (18)

Henry's understanding of his and Daisy's differing habituses extends to an ability to use the reading capital he has amassed to his economic advantage and it is primarily Henry's literary knowledge that acts as a signifier of his decency. This conception of the consumption of literature as somehow 'civilising' the reader has, of course, clear critical antecedents and Henry's social standing is heightened by the fact that he not only reads a great deal but reads the 'right' books. ${ }^{17}$ Henry is able to quote Shakespeare in casual passing $(211)^{18}$ and, when comfortably ensconced in Daisy's home and bed, to read the Brontës alongside her as she researches for a new play. Daisy is impressed by 'his perception, his sharp appreciation and his willingness to discuss what he reads' (303). Henry's practised sensitivity to literature and his frequent eulogisation of the written word - 'I'm bookstruck. Have been all my life' (113) - compensates for the initial sense of unease that Daisy feels about him, an unease she justifies by classifying it as the same snobbery about his background that her friends at times exhibit. Thus, Daisy's repeated misreadings of Henry's machinations are predicated upon 
romantic infatuation as well as a liberal determination to be non-judgemental, leading her to (mis) identify the skills of reading and writing as reliable markers of integrity and honour. Ultimately, Daisy's appraisal of Henry's literary sensibility is more romanticised than the Bourdieuian model allows: in Daisy's assessment certain types of reading become located as belonging to a realm beyond cultural construction, a space that transcends the pettiness of social divisions, or, at the very least, a place where social inequalities can be resolved. Of course, this sense of certain types of reading as culturally elevating is paradoxical as it is embedded in the same notion of social hierarchies that it claims can be eradicated via reading the right books. The fact that Howard so carefully and precisely deconstructs this view of literature and reading gives the novel a clear anti-Leavisite (or anti-Arnoldian) stance. The romance of reading is seen to have an equal capacity for deceit as for civilisation and Daisy is proved to be very wrong to place such faith in this concept of literary consumption as ennobling.

Appalled at the disjunction she perceives between Henry's cultural and material habituses 'Poor man! It is hard to imagine how someone so sensitive and intelligent could stand such a life' (278) - Daisy allows Henry to move in with her more permanently and when she does so he instigates a tradition of 'bedtime stories' (301). These stories continue the work of his earlier letters and are exactly that, stories. Daisy is learning a fabricated version of Henry's past that entertains and panders to the romanticised conception she wants to have of his working class roots. Daisy's reflexive awareness of her superior social status and the value judgements that often attend it make her prime prey for Henry's trap. Henry is both clever and amorally duplicitous ashis shameless reading of her journal and letters has given him access to the most private of her thoughts and Daisy's comment that 'he seemed to know what she was thinking' (229) is, of course, entirely accurate. Daisy believes that Henry reads her with a rare 
level of sensitivity but what Daisy diagnoses as acuity and compassion is actually the result of insider-information: '[h]e knows that I keep a diary from time to time and understands that it is a piece of writing that is entirely private to me' (303). Thus, when they share their nightly bedroom tales the sense of increased intimacy is doubly false; Daisy is revealing nothing new and Henry is revealing nothing. Henry's textual penetration of Daisy's private letters and diaries serves to foreshadow their sexual relationship and he uses this forbidden reading as foreplay; he has laid her bare long before he has undressed her. On a metareaderly level it also reveals the voyeuristic pleasures akin to reading that which is deemed private as the reader's discomfort at Henry's seduction is engendered not solely by a sense of moral outrage but also by the shared intrusion. Daisy's contributions to their nightly confidences are as familiar to the reader as they are to Henry. Henry's first-person narration works to arouse a sense of complicity on the part of the material reader: the reader has so much more information than Daisy that she feels collusive in Henry's machinations. His chapters operate as an Iago-like confessional of intent which the reader can view only helplessly from behind the fourth wall. There is excessive and uncomfortable dramatic irony at work here as Daisy is repeatedly misled and conned.

However, the car-crash mentality of watching Daisy plunge headlong into oncoming traffic is counter-balanced by the unpleasant understanding of Henry's situation. One of the challenges presented by this novel is its shifting moral framework. Henry's actions are unquestionably unethical but in allowing the reader access to his motivations from the start of his campaign, Howard makes it increasingly difficult to judge him. Some of the chill that comes from reading the text is precisely because Henry Kent is not just a callous, manipulative monster but also a charming, well-read, attentive, conversational man who has learnt how to care for and please women. The fact that this care and pleasure is based upon a 
desire for his own material comfort does not, necessarily, negate it. Romance is evoked as a superficial device, as a web-spinning means towards a more financially secure end, rather than a mystical experience. Henry's plan to seduce Daisy is romance stripped bare of its discursive construction, yet he employs the discourse with practised skill to ensure her capture. This enactment of a calculated seduction highlights the extent to which romance is always in part a contrivance and the reader's unease is augmented by uncomfortable recognition of the devices Henry deploys.

Eventually, Howard forces the reader to condemn Henry for his violence but an attendant, two-fold guilt complicates this: the collusion in Daisy's deception is accompanied by a sense of conspiring with a status judgement that locates Henry, however well-read, as decidedly lacking the manners and tastes of the moneyed middle-classes. Thus, the novel's careful unpacking of the romanticisation of reading is underpinned by a class politics that, while revealing reading as not equally accessible to all, demands an assessment that reinforces this inequality. Howard's nuanced critique of Arnoldian/Leavisite elitisms therefore loses some of its cogency towards the close of the novel as Henry is increasingly caricatured as an aggressive, drink-fuelled man, desperate to finally shake-off his working class shackles. However, the power dynamics of the novel are not just about class but also gender. Henry compensates for his sense of disenfranchisement by adeptly employing the mythology of (heterosexual) romance to inculcate the privileges of patriarchal dominance. Henry offers women something they (will always) lack because it is a fiction, a 'true romance' that fulfils the promises of its discursive construction by way of companionship, conversation, attentiveness and endlessly pleasurable sex. Henry reads Daisy through his extensive knowledge of romantic discourse: 
'[i]f you can please a woman in bed $[\ldots]$ you have her $[\ldots]$ she will invent the rest of you to suit her romantic excuses, and if you lapse she will make allowances of the most ingenious and sensitive kind' (243).

Although some of this knowledge has been gained through experience, it has been expanded upon and refined through a lifetime of reading. But Henry is also cognisant of the potential of reading capital as a romance in itself and in displaying his literary wares as flirtatious seduction he simultaneously asserts his suit(or)able credentials and rewrites his background. Henry's roles as reader and writer are determinedly active as he employs his reading to shape his writing and conversation as a means to an economic end. By comparison, Daisy's reading is passive or, at best, reactive for, despite her career as a playwright, Daisy reads what she would like to read rather than what she can potentially discern and she is gravely punished for this failure to read with care. The reader sits uncomfortably poised between these two positions, fully aware of and appalled by Henry's creative practices but increasingly frustrated by Daisy's wilful naivety. However, the unravelling of Henry's lies reveals that his narration to the reader has also been highly selective in that he has glossed over most extreme elements of his behaviour, particularly his propensity for violence. There is an uneasy sense that even his direct addresses are, in part at least, smoke and mirrors and completing the novel leaves a feeling of possibly being as duped and deluded as its female protagonist by the storytelling proclivities of Henry Kent.

In over-compensating for the class inequalities between herself and Henry, Daisy fails to take into account the cultural construction of gender that also scripts the interaction between herself and her gardener and by the close of the book the age-old battle lines of class and gender politics are savagely re-instated rather than redrawn: Henry is cast out from a life of potential comfort that he has always enviously espied from afar and Daisy is left reeling 
again at men's capacity for treachery and deceit. Nevertheless, Henry's comeuppance is brief and Falling's final page sees him deciding to 'think of it merely as an unfortunate incident' as he turns his attentions to a well-dressed woman whom he has spotted sitting alone reading in a train carriage (422). Once more it is the signifieds of reading that prompt the connection. Howard's parting shot underlines the tenacity of the discourse of romance and its inherent gender bias as while Daisy has retreated to Greece to be slowly comforted into believing that she 'will get over that horrid old shit'(417), Henry is forever poised at the very edge of the text, his irrepressible ego readied for another seductive attack. Moreover, the inclusion of the detail that his next potential target is reading foregrounds the ways in which this practice, for all the wonders that may attend its enactment, is a culturally derived and politically inscribed performance. Both Daisy Langrish and the material reader must learn that the seductions of the text are about more than what is written on the page.

In Falling reading is unethically deployed and mistakenly over-romanticised, inextricably bound to not only duplicitous and cruel modes of courtship but also to the satisfaction of hegemonically sanctioned yet delusional desires. Whereas Possession and The PowerBook take recourse in highly romanticised representations of reading that do little, if anything, to articulate hierarchies of difference, Howard's small-scale, domestic, realist novel actively and controversially problematises reading and refuses to rescue it from its entanglement with the operations of power and privilege, as starkly highlighted by Howard's denial of any form of conventional solace at the close of this brutal romance. Thus the novel's metareaderly elements intervene in a series of academic debates that circulate around the woman reader and women's reading but they also insist upon a reconsideration of what reading can $d o$. This is particularly foregrounded in the discomfort that accompanies the reading of the novel, as the protagonists' disappointments, their misreadings of both reading itself and each other, is 
mirrored in the material reader's realisation that reading may be a potential romance but it is equally a potential disaster. In the special issue of NOVEL cited in the introduction to this paper, feminist critic Kate Flint positions reading as 'a paradoxical business' (19) and insists that it is time to "think about the fact that reading may have decidedly less than positive results' (20) and asks 'what [...] do we do with the reading that produces non-pleasurable responses, and how adequately do our theories cope with it?' (21). One of the ways that the literary academy might address these concerns is as demonstrated in this paper, that is, through careful and considered analyses of the metareaderly components and functions of contemporary fiction.

With thanks to Margaret Beetham and Emma Liggins for comments on earlier drafts of this work.

\footnotetext{
${ }^{1}$ Recent examples of the ways in which the study of reading and reading practices have developed include: Flesch, Wolf and Zunshine.

${ }^{2}$ See: Whelehan, Harzewski

${ }^{3}$ See: Ramone and Cousins.

${ }^{4}$ The singular noun 'reader' is used throughout for stylistic reasons but it must be noted that there is never a single, textually-determined reader; the 'reader' is always multiple and heterogeneous even if she may not be addressed as such.

${ }^{5}$ The coinage of this term avoids the clumsy repetition of the phrase 'texts which represent the reader and acts of reading.'

${ }^{6}$ Critics have repeatedly rescued the woman reader from this prescribed location, both historically, for example, Flint, Jack and theoretically, for example, Fetterley, Flynn and Schweickart, Mills. However, the stereotype of 'women's fiction' is persistent and attaches itself with particular tenacity to middlebrow novels and the popular romance (cf. Brown and Grover, Humble, Modelski, Radway).
}

${ }^{7}$ Cf. on Byatt: Buxton, Flegel; on Winterson: Grice and Woods and Palmer

${ }^{8}$ As Jago Morrison has argued, Winterson's evocation of homosexual desire does little to trouble and, arguably, replicates the myths of the heterosexual romance.

${ }^{9}$ For a more detailed account of the representations of reading in three of Winterson's novels see: Carpenter.

${ }^{10}$ The Light Years (1990), Marking Time (1991), Confusion (1993), Casting Off (1995). A fifth book - All Change - was published in November 2013, less than two months prior to Howard's death.. 
${ }^{12}$ Falling is also highly metafictional as Henry deploys various storytelling techniques to captivate Daisy. However, the concerns of this article are pointedly about the text's metareaderly features in order to both privilege reading and to foreground the congruence between reading and romance.

13 The use of the term 'blow' throughout the novel for both emotional and physical trauma intertextually references Rochester's use of the word in Jane Eyre when he discovers Richard Mason has visited Thornfield“"Jane, I've got a blow; I've got a blow, Jane!"' (203) - and reinforces Henry's presumptuous positioning of himself as romantic lead.

${ }^{14}$ Daisy's name is, of course, itself a nod to The Great Gatsby.

${ }^{15}$ The idea of reading as a process of resistance is taken, of course, from Judith Fetterley.

${ }^{16}$ See: Bourdieu, particularly Part 1and specifically 53-54.

${ }^{17}$ Cf.: Eliot, Arnold, Q.D.Leavis, F.R Leavis.

${ }^{18}$ Henry quotes from Sonnet 57 - 'I have no precious time at all to spend' - when assuring Daisy that he is free to drive her whenever and wherever she wishes.

\section{Works Cited}

Arnold, Matthew. Culture and Anarchy: An Essay in Political and Social Criticism. Ed.

J. Dover Wilson, Cambridge: Cambridge University Press, 1990.

Austen, Jane. Northanger Abbey . Oxford: Oxford World Classics, 2003.

Barthes, Roland. 'On Reading'. The Rustle of Language.Trans. by Richard Howard, Oxford: Basil Blackwell, 1986. 3-46.

Bourdieu, Pierre. Distinction: A Social Critique of the Judgement of Taste. London: Routledge, 1979.

Bronte, Charlotte. Jane Eyre . Oxford: Oxford World Classics, 2000.

Brown, Erica and Mary Grover (eds).Middlebrow Literary Cultures: the Battle of the Brows, 1920-1960. Basingstoke: Palgrave Macmillan, 2011.

Buxton, Jackie, 'What's Love Got to do With It? Postmodernism and Possession', English Studies in Canada, 22 (1996), 199-219.

Byatt, A.S., Possession: A Romance. London: Vintage, 1990.

Carpenter, Ginette. 'Reading and the Reader'. Jeanette Winterson: A Contemporary Critical

Guide. Ed. Sonya Andermahr, London: Continuum, 2007. 69-81.

Dällenbach, Lucien. The Mirror and the Text. Trans. by Jeremy Whiteley with Emma Hughes 
Cambridge: Polity Press, 1989.

de Certeau, Michel. 'Reading as Poaching'. The Practice of Everyday Life. Trans. by

Steven Rendall, Berkley: University of California Press, 1984, 165-176.

Eliot, George, 'The Natural History of German Life.' The Westminster Review (July 1856).

66 (old series), 10 (new series): 51-7. Web. $7^{\text {th }}$ January 2014.

$<\underline{\text { http://ebooks.adelaide.edu.au/e/eliot/george/e42e/chapter5.html }>\text {.Fetterley, Judith. The }}$

Resisting Reader: A Feminist Approach to American Fiction. Bloomington:

Indiana University Press, 1977.

Flegel, Monica. 'Enchanted Readings and Fairy Tale Endings in A.S. Byatt's Possession.' English Studies in Canada 24 (1998): 413-430.

Flesch, William. Comeuppance: Costly Signalling, Altruistic Punishment, and Other Biological Components of Fiction. Cambridge, Mass.,Harvard University Press, 2009.

Flint, Kate. The Woman Reader 1837-1914. Oxford: Oxford University Press, 1993.

Flint, Kate. 'What can Reading Do.' Novel: A Forum on Fiction 43.1 (2012):19-21.

Flynn, Elizabeth A. and Patrocinio Schweickart (eds). Gender and Reading: Essays on Readers,

Texts, and Contexts. Baltimore: The John Hopkins University Press, 1986.

Fowler, Christopher. 'Forgotten Authors No. 58: Elizabeth Jane Howard.' Independent on

Sunday, 7Nov 2010. Web. $25^{\text {th }}$ October $2012<$ http://www.independent.co.uk/arts-

entertainment/books/features/forgotten-authors-no-58-elizabeth-jane-howard-2124434.html>.

Friedan, Betty. The Feminine Mystique. London: Penguin, 1963.

Gindin, James. ‘Elizabeth Jane Howard'. Contemporary Novelists.

Ed. Susan Windisch Brown. New York: St James Press, 1996, $6^{\text {th }}$ edn, 496-499.

Greer, Germaine. The Female Eunuch. London: Paladin, 1971.

Grice, Helena and Tim Woods (eds). 'I'm Telling You Stories': Jeanette Winterson and the Politics of Reading. Amsterdam: Rodopi, 1998.

Harman, Claire. 'The End of an Era.'Times Literary Supplement. 10 Nov,1995. 
Web. $4^{\text {th }}$ January 2014. < http://www.thetls.co.uk/tls/reviews/fiction/article744981.ece >.Harweski, Stephanie. Chicklit and Postfeminism. London: University of Virginia Press, 2011.

Howard, Elizabeth Jane.Falling. London: Pan, 2000.

The Long View.London: Pan, 1995.

Odd Girl Out. London: Pan, 1995.

The Sea Change. London: Macmillan, 1994.

Slipstream. London: Pan, 2003.

Hutcheon, Linda. Narcissistic Narrative: The Metafictional Paradox. London: Methuen, 1984, $2^{\text {nd }} e d n$.

Jack, Belinda. The Woman Reader. New Haven: Yale University Press, 2012.

Jüngst, Heike Elisabeth. 'Elizabeth Jane Howard'. Modern British Women Writers: An A-Z

Guide.Ed. Vicki K. Janik and Del Ivan Janik. Westport, CT: Greenwood Press, 2002. 153-158.

Keyes, Marian. The Other Side of the Story. London: Penguin, 2005.

Leavis, Q.D.. Fiction and the Reading Public. London: Chatto and Windus, 1965.

Leavis, F.R.. The Great Tradition. Penguin: Harmondsworth, 1972.

Litt, Toby and Ali Smith. 'Introduction.' New Writing: 13. London: Picador, 2005, ix-xi.

Littau, Karin. Theories of Reading: Books, Bodies and Biblomania. Cambridge: Polity, 2006.

Millett, Kate. Sexual Politics.London: Virago, 1977.

Mills, Sara (ed.). Gendering the Reader. London: Harvester Wheatsheaf, 1994.

Modleski, Tania. Loving with a Vengeance: Mass-produced Fantasies for Women. New York: Methuen, 1982.

Morrisson, Jago. 'Who Cares About Gender at a Time Like This?' Love, Sex and the Problem of Jeanette Winterson.',Journal of Gender Studies.15 (2006): 169-180.

Noble, Elizabeth. The Reading Group. London: Coronet, 2004.

Palmer, Paulina. 'Jeanette Winterson and the Lesbian Postmodern.'The Contemporary British Novel. Ed. James Acheson, and Sarah C.E. Ross. Edinburgh: Edinburgh University Press, 2005. 189-199. 
Parker, Emma (ed.),Contemporary British Women Writers, Cambridge: The English Association, 2004.

Pearce, Lynne, Feminism and the Politics of Reading, London: Arnold, 1997.

Pearce, Lynne and Gina Wisker (eds), Fatal Attractions: Re-scripting Romance in Contemporary Literature and Film, London: Pluto Press, 1998.

Pearce, Lynne and Jackie Stacey (eds), Romance Revisited, New York: New York University Press, 1995.

Picardie, Justine. Daphne. London: Bloomsbury, 2008.

Radway, Janice A., Reading the Romance: Women, Patriarchy and Popular Literature, London: The University of North Carolina Press, $1991,2^{\text {nd }}$ edn.

Ramone, Jenni and Helen Cousins, The Richard and Judy Book Club Reader: Popular Texts and the Practices of Reading, London: Ashgate, 2011.

Rooney, Ellen, 'Introduction: Reading Effects', Novel: A Forum on Fiction, 43.1 (2012) 1-2.

Setterfield, Diane. The Thirteenth Tale. London: Orion, 2006.

Turner, Nick. Post-War British Women Novelists and the Canon . London: Continuum, 2010.

Janet Watts. 'Elizabeth Jane Howard Obituary.' The Guardian. 2 Jan 2014. Web. $3^{\text {rd }}$ January 2014 $<$ http://www.theguardian.com/books/2014/jan/02/elizabeth-jane-howard-dies-90 $>$

Waugh, Patricia. Metafiction: The Theory and Practice of Self-Conscious Fiction. London and New York: Methuen, 1984.

Winterson, Jeanette. The PowerBook. London: Vintage, 2001.

Wolf, Maryanne. Proust and the Squid: The Story and Science of the Reading Brain. Cambridge: Icon Books: 2008.

Woolf, Virginia. 'Middlebrow'. (Unpublished letter to the New Statesman.) The Death of the Moth and Other Essays. Web $8^{\text {th }}$ October 2012.

$<$ http://ebooks.adelaide.edu.au/w/woolf/virginia/w91d/chapter22.html > .

Woolf, Virginia. A Room of One's Own. London: Grafton, 1977.

Zunshine, Lisa. Why We Read Fiction: Theory of Mind and the Novel. Columbus: Ohio, 2006. 
